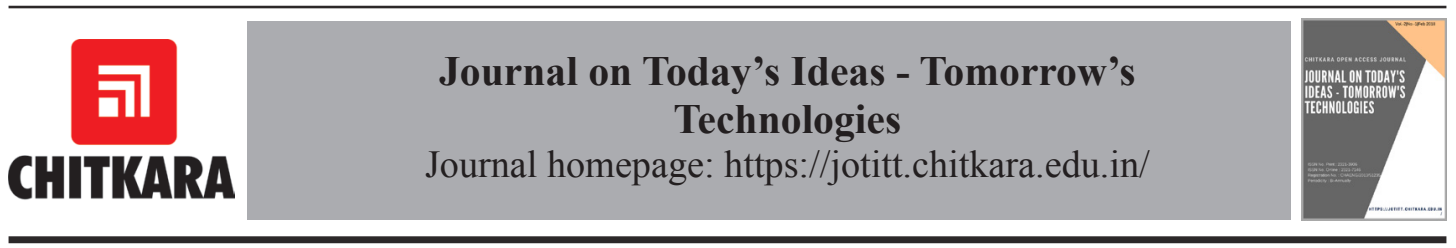

\title{
Comparative Study of Seismic Analysis of Pier Supported on Pile as per IRC:6-2017 and IRC SP:1 14-2018
}

\author{
Vivek Gajera $^{1}$, V. R. Panchal ${ }^{2}$, Vishal Vadgama ${ }^{3}$ \\ ${ }^{1,2}$ Charotar University of Science and Technology (CHARUSAT), Changa, Gujarat, India. \\ ${ }^{3}$ DGM Structures, Infinite Civil Solutions Pvt Ltd, Ahmedabad, Gujarat, India.
}

1Email: vivekgajera12@gmail.com

ARTICLE INFORMATION

DOI: $10.15415 /$ jotitt.2019.71002

Keywords: Bridge Pier, Seismic analysis, IRC:6-2017,IRC

SP: $114-2018$

\begin{abstract}
This paper depicts the study of seismic analysis of reinforced concrete bridge piers as per provisions of Indian Road Congress (IRC) guidelines. Bridges are designed having two main structural elements named - "Superstructure" and "Substructure". Superstructure consists of deck and supporting girder/ truss system below deck. Substructure includes Abutments, Piers, Portals and Foundations. Amongst these, Abutments/Piers are crucial part of bridge. Therefore, as per the seismic design philosophy, it is necessary to study the seismic behaviour of bridge piers. With the advancements in technology and subsequent researches in Infrastructure fields, IRC guidelines are updated and revised time-to-time. Introduction of IRC SP:114-2018 guideline for earthquake forces in bridges is an example of such developments. In this research, seismic analysis of Reinforced Cement Concrete (RCC) bridge pier is carried out as per provisions of prevailing guideline IRC:6-2017. Base shear value of IRC:6-2017 is compared with IRC SP:114-2018 which now supersedes seismic provisions of IRC:6-2017. For analysis, different span lengths of $25 \mathrm{~m}, 30$ $\mathrm{m}$ and $36 \mathrm{~m}$ are used. To assess the impact of height of piers in earthquake analysis, various pier heights such as $10 \mathrm{~m}, 20 \mathrm{~m}$ and $30 \mathrm{~m}$ are assumed. The analysis is carried out as per Elastic Seismic Acceleration Method with consideration of different zones and importance of the bridge as per IRC guidelines. Effect of vertical ground motion is also considered in analysis. From analysis, it is observed that base shear and vertical forces have been increased remarkably as per IRC SP:114-2018 compared to IRC:6-2017.
\end{abstract}

\section{Introduction}

The bridge may be defined as a structure which provides transportation facilities over physical obstacles such as valley, water body, road, railway as well as design of the bridges are dependent on its function, nature of terrain, materials used etc. An earthquake collapse of bridge will affect lives of people as well as property and cause economic losses [1]. According to seismic design philosophy, the engineer should intend to provide 
earthquake resistant design instead of aiming to provide earthquake proof design. Therefore, it is very important to analyse the seismic behaviour of a bridge and make its structure seismic resistant for preventing hazardous losses.

For substructure analysis, seismic forces are one of the most disastrous forces on the earth. The seismic force acts on the centre of gravity of structural components in the horizontal direction. The main function of the pier is to support the spans of the bridge and transfer the loads from superstructure to the foundation. Thus, it should be strong enough to take both vertical and horizontal loads [Q]. However, piers are subjected to huge axial loads and biaxial moments in transverse and longitudinal directions.

As per history of Indian codes, it can be seen that there have been significant developments in last thirty years. However, Indian practices have not kept pace and seismic provision for bridges are highly inadequate. However, there is a serious earthquake problem in large part of the country and revisions of Indian codes are infrequent.

Generally, structural designers don't consider effect of vertical motion in seismic design of the pier. But measurement of ground motion during past earthquakes demonstrate that the vertical acceleration may exceed the horizontal acceleration. Therefore, it is necessary to analyse the effect of vertical motion in the pier [3].

After publishing of the guideline of IRC SP:114-2018, the existing provisions for seismic design in Clause 219 of IRC:6-2017 stand superseded $[4,5]$. Thus, it is required to find out the difference in this code.

In this study comparison of seismic analysis of bridge substructure (pier) as per IRC SP:114-2018 and IRC:6-2017 accordingly its seismic clauses are investigated. For that, various pier heights such as $10 \mathrm{~m}, 20 \mathrm{~m}, 30 \mathrm{~m}$ and different span lengths such as $25 \mathrm{~m}, 30 \mathrm{~m}, 36 \mathrm{~m}$ are considered.

\section{Preliminary comparison of IRC:6-2017 and IRC SP:114- 2018}

Various clauses of IRC:6-2017 and IRC SP:1142018 is reviewed and compared in Table 1 . It is observed that various important parameters are updated in IRC SP:114-2018. From table it is seen that more clarity is given for Special Investigation in various situations. Time History method is incorporated in latest code. Vertical seismic calculation is more elaborated and minimum design earthquake coefficient is given in IRC SP:114-2018. More of the briefs are found in Table 1.

Table 1: Comparison of IRC:6-2017 and IRC SP:114-2018

\begin{tabular}{|c|c|}
\hline IRC:6-2017 & IRC SP: $114-2018$ \\
\hline Clause 219.1.1 & Clause 2.3 \\
\hline Following types of bridges need not to be checked & Following types of bridges \\
\hline for seismic effects: & for seismic effects: \\
\hline $\begin{array}{l}\text { - Culverts and minor bridges up to } 10 \mathrm{~m} \\
\text { length in all seismic Zones. }\end{array}$ & $\begin{array}{l}\text { - Culverts and minor bridges up to } 10 \mathrm{~m} \\
\text { length in all seismic Zones. }\end{array}$ \\
\hline $\begin{array}{l}\text { Bridges in seismic Zones II and III satisfying } \\
\text { both limits of total length not exceeding } 60 \\
\mathrm{~m} \text { and spans not exceeding } 15 \mathrm{~m} \text {. }\end{array}$ & $\begin{array}{l}\text { - Bridges in seismic Zones II and III sat- } \\
\text { isfying both limits of total length not ex- } \\
\text { ceeding } 60 \mathrm{~m} \text { and individual simply supported } \\
\text { spans not exceeding } 15 \mathrm{~m} \text {. } \\
\text { The dynamic earth pressure on abutments } \\
\text { during earthquake shall not be considered in } \\
\text { Zones II and III. }\end{array}$ \\
\hline
\end{tabular}

ISSN No.: 232 1-3906 (Print) ISSN No.: 2321-7146 (Online) Registration No.: CHAENG/2013/51235 Periodicity: Bi-Annually 


\begin{tabular}{|c|c|}
\hline \multicolumn{2}{|c|}{ Table 1 [Continued] } \\
\hline$\frac{\text { Clause 2 19.1.2 }}{\text { Special Investigation }}$ & $\begin{array}{l}\text { Clause 2.6.1.1 } \\
\text { In Special Investigation, following situations are } \\
\text { included: } \\
\text { - Geological discontinuity exists at the site } \\
\text { - } \quad \text { Site with loose sand or poorly graded sands } \\
\text { with little or no fines, liquefiable soil } \\
\text { - Special types of bridges: Bascule Bridge, } \\
\text { Horizontally Curved Girder Bridge hav- } \\
\text { ing } \leq 100 \text { m radius, Bridge with high skew } \\
\geq 30 \text { degree, Seismically isolated bridges, } \\
\text { Bridges with Passive Dissipating Devices } \\
\text { (PED), Bridges with Shock Transmission } \\
\text { Unit (STU), Bridges with Innovative De- } \\
\text { signs }\end{array}$ \\
\hline $\begin{array}{l}\text { Clause } 216.1 .2 \\
\text { Need for Special investigation } \\
\text { - } \quad \text { No specification for which bridge and } \\
\text { conditions, which special study is re- } \\
\quad \text { quired. }\end{array}$ & $\begin{array}{l}\text { Clause 2.6.1.2 } \\
\text { Detailed Seismic Studies } \\
\text { - } \quad \begin{array}{l}\text { Elaborated different cases in which ad- } \\
\text { ditional special studies or analysis is re- } \\
\text { quired. }\end{array}\end{array}$ \\
\hline $\begin{array}{l}\text { Clause } 219.3 \\
\text { Vertical component of Seismic action } \\
-\quad \text { Two-third of horizontal component }\end{array}$ & \begin{tabular}{|l} 
Clause 4.2.3 \\
Vertical component of Seismic action \\
$-\quad$ Analysis for vertical seismic action re- \\
quires time period of superstructure in \\
vertical direction and equation for time \\
period is given. \\
The spectra for vertical ground motions may be \\
taken as two-thirds of that for horizontal motions.
\end{tabular} \\
\hline $\begin{array}{l}\text { Clause } 219.5 \\
\text { Computation of Seismic Response } \\
-\quad \text { Elastic Seismic Coefficient Method } \\
-\quad \text { Elastic Response Spectrum Method } \\
\text { Spectra for seismic coefficient method is same as } \\
\text { spectra for response spectrum method. } \\
\text { Design acceleration coefficient }\left(S_{a} / g\right) \text { for different } \\
\text { soil types is same for both methods. }\end{array}$ & $\begin{array}{l}\text { Clause 5.2 } \\
\text { Seismic Analysis Methods } \\
\quad-\quad \text { Elastic Seismic Coefficient Method } \\
-\quad \text { Elastic Response Spectrum Method } \\
-\quad \text { Time History Method } \\
\text { Spectra for seismic coefficient method is different } \\
\text { from spectra for response spectrum method. } \\
\text { Design acceleration coefficient }\left(S_{a} / g\right) \text { for different } \\
\text { soil types is different for both methods. } \\
\text { Requirements of method of seismic analysis for } \\
\text { different types of bridges are given. }\end{array}$ \\
\hline $\begin{array}{l}\text { Clause } 216.1 .2 \\
\text { Classification of different types of soil for deter- } \\
\text { mining the spectrum is not given in details. }\end{array}$ & $\begin{array}{l}\text { Clause } 5.2 .3 \\
\text { Classification of different types of soil for deter- } \\
\text { mining the spectrum is given in detail to estimate } \\
\text { design earthquake force. }\end{array}$ \\
\hline $\begin{array}{l}\text { No Existing Clause } \\
\text { Minimum Design Horizontal Seismic Accelera- } \\
\text { tion Coefficient }\left(A_{h}\right) \text { is not specified. }\end{array}$ & $\begin{array}{l}\text { Clause } 5.4 \\
\text { Minimum Design Horizontal Seismic Accelera- } \\
\text { tion Coefficient }\left(A_{h}\right) \text { is specified. }\end{array}$ \\
\hline
\end{tabular}

ISSN No.: 232 1-3906 (Print) ISSN No.: 2321-7146 (Online) Registration No.: CHAENG/2013/51235 Periodicity: Bi-Annually 


\begin{tabular}{|l|l|}
\hline \multicolumn{2}{|c|}{ Table $1[$ Continued $]$} \\
\hline $\begin{array}{l}\text { Clause 219.5.5 } \\
\text { Response reduction factor for superstructure is given. }\end{array}$ & $\begin{array}{l}\text { Clause 4.2.4 } \\
\text { Response reduction factor for superstructure is removed. }\end{array}$ \\
\hline $\begin{array}{l}\text { Clause 219.5.1.1 } \\
\text { Importance factor is not specified in detail for } \\
\text { bridges crossing railway lines. }\end{array}$ & $\begin{array}{l}\text { Clause 4.5 } \\
\text { Importance factor is specified in detail for bridges } \\
\text { crossing railway lines. }\end{array}$ \\
\hline $\begin{array}{l}\text { Clause 219.1.2 } \\
\text { Soil structure interaction criteria is not specified } \\
\text { in detail. }\end{array}$ & $\begin{array}{l}\text { Clause 4.4 } \\
\text { Soil structure interaction criteria is specified in } \\
\text { detail. }\end{array}$ \\
\hline $\begin{array}{l}\text { Clause 219.5.4 } \\
\text { tions are not specified. }\end{array}$ & $\begin{array}{l}\text { Clause 4.8 } \\
\text { Hydrodynamic forces on bridge piers and foun- } \\
\text { dations are specified as well as equation for total } \\
\text { horizontal force is elaborated. }\end{array}$ \\
\hline $\begin{array}{l}\text { No Existing Clause } \\
\text { Clause 3.1 (New Clause Added) }\end{array}$ \\
$\begin{array}{l}\text { This includes the criteria for site selection, se- } \\
\text { lection of bridge structural configuration based } \\
\text { on seismic behaviour, choice of articulation sys- } \\
\text { tem such as bearing and expansion joints, effect } \\
\text { of time period on design of bridges \& structural } \\
\text { ductility and energy dissipation. }\end{array}$ \\
\hline
\end{tabular}

\section{Validation of work}

Validation of work is done with paper entitled 'Comparative Study of DDBD and FBD For Elevated Metro Bridge Substructure' published by Desai \& Vyas [2].

Parametric Study of Metro Bridge pier has been considered in research paper with various spans of superstructure and different heights of piers.

Comparative results of base shear are shown in Table 2.

Base shear value is inversely proportional to height of pier. As height of pier increases, base shear value decreases. From the table, it is observed that base shear value is nearly identical to research paper calculations.

\section{Load calculations}

The bridge superstructures consist of Precast Prestressed Concrete (PSC) girders having $30 \mathrm{~m}$ length of span. The height of pier is considered as $10 \mathrm{~m}, 20 \mathrm{~m}$ and $30 \mathrm{~m}$ having a circular cross-section of $2 \mathrm{~m}$ diameter. The proposed bridge located in seismic Zone $\mathrm{V}$ and soil type is hard soil. The seismic forces are calculated as per IRC:6-2017 and IRC SP:1142018. The static horizontal seismic force on the bridge is calculated based on horizontal seismic coefficient and weight at the vertical centre of mass of a structure. The material properties for the analysis are given below.

Density of concrete $=25 \mathrm{kN} / \mathrm{m}^{3}$

Grade of concrete $=$ M45

Elastic modulus of Concrete $\left(E_{c m}\right)$ $=34000 \mathrm{~N} / \mathrm{mm}^{2}$ [6]

Table 2: Comparative results of base shear

\begin{tabular}{|c|c|c|c|c|}
\hline Height & $8 \mathrm{~m}$ & $10 \mathrm{~m}$ & $12 \mathrm{~m}$ & $15 \mathrm{~m}$ \\
\hline Desai \& Vyas [2] $(\mathrm{kN})$ & 993 & 780 & 637 & 494 \\
\hline STAAD.Pro $(\mathrm{kN})$ & 993.149 & 780.362 & 636.752 & 493.523 \\
\hline
\end{tabular}

ISSN No.: 232 1-3906 (Print) ISSN No.: 2321-7146 (Online) Registration No.: CHAENG/2013/51235 Periodicity: Bi-Annually 
Density of wearing coat $=22 \mathrm{kN} / \mathrm{m}^{3}$

Grade of Steel $=\mathrm{Fe} 500$

Density of Steel $=78.5 \mathrm{kN} / \mathrm{m}^{3}$

Elastic modulus of steel $=200000 \mathrm{~N} / \mathrm{mm}^{2}$

For analysis, the dead weight of superstructure and substructure, live load as well as seismic load on the pier are considered. and braking effect is considered.

The live load combinations for four lane carriage way are considered as per Table 3, IRC:6-2017.

\section{Parameter for Substructure}

Type of pier
- Circular column type

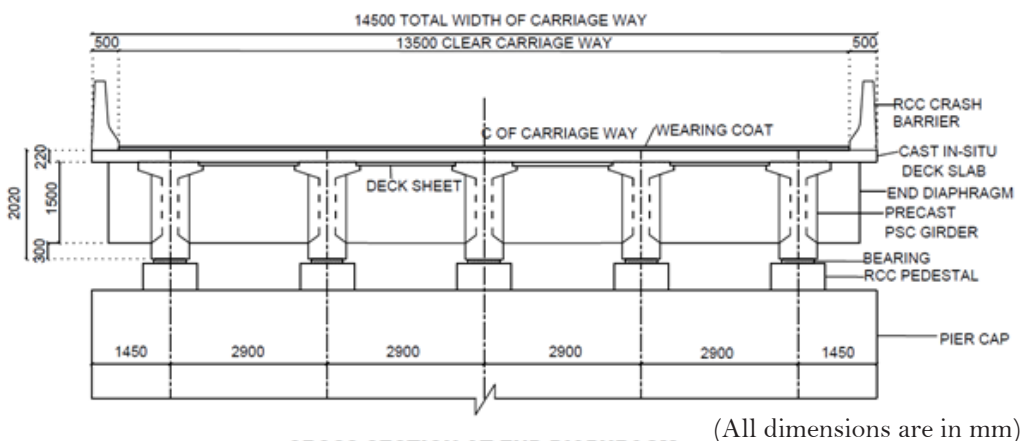

CROSS SECTION AT END DIAPHRAGM

(All dimensions are in $\mathrm{mm}$ )

Figure 1: Cross-section for $30 \mathrm{~m}$ span

The superstructure consists of the girders, deck slab, and crash barriers. The width of the deck slab is $14.5 \mathrm{~m}$ which includes crash barrier of $0.5 \mathrm{~m}$ on both sides as shown in Fig. 1. The width of carriageway is $13.5 \mathrm{~m}$, four-lane highway bridge. The depth of the deck slab is $0.22 \mathrm{~m}$ and thickness of wearing coat is 0.075 $\mathrm{m}$. There are end diaphragms of $0.4 \mathrm{~m}$ thick and $1.5 \mathrm{~m}$ height as well as two intermediate diaphragms of $0.3 \mathrm{~m}$ thick and $1.5 \mathrm{~m}$ height.

Two types of vehicle such as Class 7oR and Class A are considered. Moreover, the effect of eccentric load due to vehicle live load
Height of pier

Diameter of pier

Effective span

\section{Loading Parameter}

DL of superstructure - $6624 \mathrm{kN}$

SIDL + Surfacing

- $1193 \mathrm{kN}$

DL of substructure

Live load

- $4567.3 \mathrm{kN}$

- $1658 \mathrm{kN}$

\section{Results of analysis}

Calculation of Base shear

\subsection{Longitudinal direction}

Table 3: Base Shear for different heights $(\mathrm{kN})$

\begin{tabular}{|c|c|c|c|}
\hline Base Shear & $10 \mathrm{~m}$ & $20 \mathrm{~m}$ & $30 \mathrm{~m}$ \\
\hline IRC:6-2017 & 1079.26 & 409.29 & 237.88 \\
\hline IRC SP:114-2018 & 1079.26 & 440.76 & 470.61 \\
\hline \% Difference & 0 & 7.69 & 97.84 \\
\hline
\end{tabular}

ISSN No.: 232 1-3906 (Print) ISSN No.: 2321-7146 (Online) Registration No.: CHAENG/2013/51235 Periodicity: Bi-Annually 


\subsection{Transverse Direction}

Table 4: Base shear for different heights $(\mathrm{kN})$

\begin{tabular}{|c|c|c|c|}
\hline Base Shear & $10 \mathrm{~m}$ & $20 \mathrm{~m}$ & $30 \mathrm{~m}$ \\
\hline IRC:6-2017 & 1089.49 & 412.337 & 239.22 \\
\hline IRC SP:114-2018 & 1089.48 & 453.364 & 483.21 \\
\hline \% Difference & 0 & 9.95 & 101.994 \\
\hline
\end{tabular}

Design horizontal seismic coefficient $\left(A_{h}\right)$ are mentioned in Fig. $2 \& 3$. for different spans and different heights

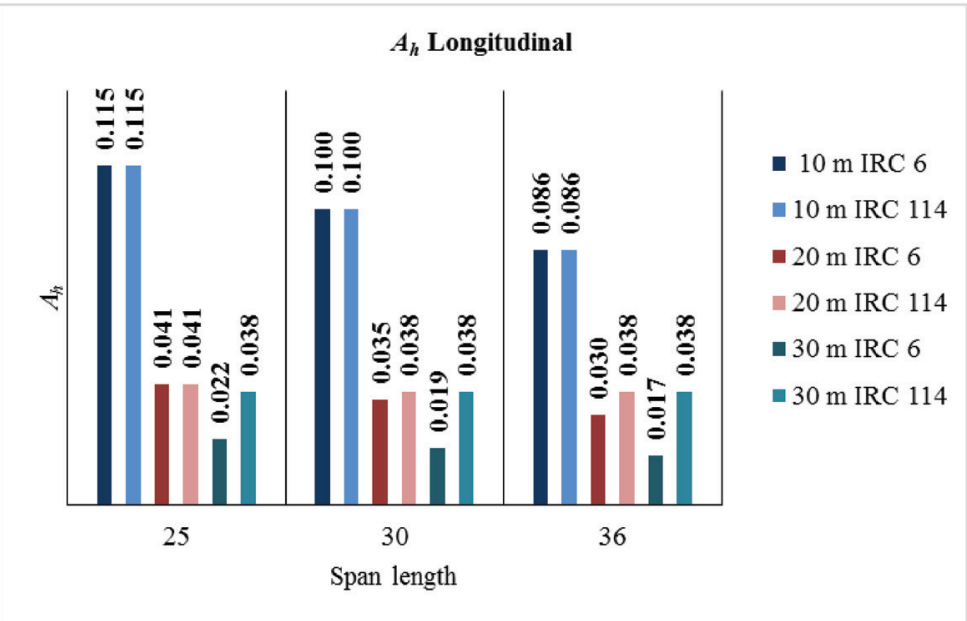

Figure 2: Horizontal seismic coefficients for different spans \& heights

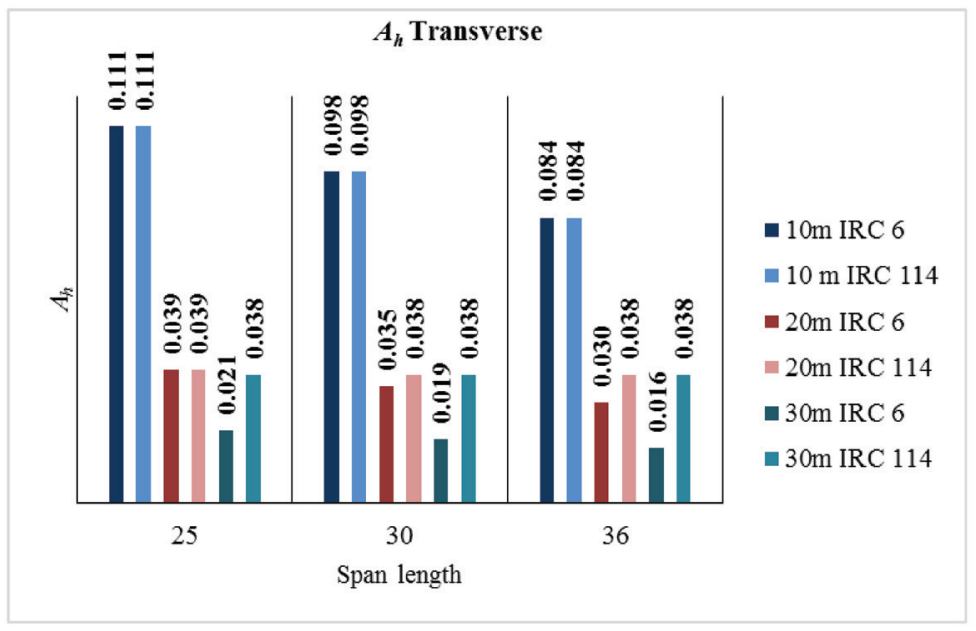

Figure 3: Horizontal seismic coefficients for different spans \& heights 
As per observation, it can be said that as height increases the value of base shear decreases. However, base shear depends on design horizontal seismic coefficient. Minimum design horizontal coefficient as per IRC SP: 114-2018 for Zone V is 0.038 and due to this, the value of base shear differs for $20 \mathrm{~m}$ and $30 \mathrm{~m}$ height as shown in Tables $3 \& 4$.

For $30 \mathrm{~m}$ height and $36 \mathrm{~m}$ span, value of time period in longitudinal direction $4.35 \mathrm{sec}$ and in transverse direction $4.44 \mathrm{sec}$. These values of time period are greater than $4 \mathrm{sec}$. Design acceleration coefficient $\left(S_{a} / g\right)$ is not given for time period greater than $4 \mathrm{sec}$ in IRC:6-2017 Clause 219.5.1. But, design acceleration coefficient $\left(S_{a} / g\right)$ for time period greater than $4 \mathrm{sec}$ is specified in IRC SP:1142018.

\subsection{Vertical component for different heights}

Analysis of vertical seismic component is based on two third of horizontal component as per IRC:6-2017. As per IRC SP:1142018, effect of vertical component is based on time period of superstructure in vertical direction. Therefore, difference in vertical seismic force as per both codes are mentioned in Table 5.

\section{Bridge crossing railway lines}

If the same bridge is crossing more than two railway lines importance factor increases from 1.2 to 1.5. Accordingly, base shear \& horizontal seismic coefficient $\left(A_{h}\right)$ are tabulated as below in Tables $6 \& 7$.

Table 5: Vertical force for different heights $(\mathrm{kN})$

\begin{tabular}{|c|c|c|c|}
\hline Vertical Force & $10 \mathrm{~m}$ & $20 \mathrm{~m}$ & $30 \mathrm{~m}$ \\
\hline IRC:6-2017 & 726.33 & 274.89 & 159.48 \\
\hline IRC SP:114-2018 & 363.675 & 363.675 & 363.675 \\
\hline \% Difference & -49.92 & 32.30 & 128.04 \\
\hline
\end{tabular}

\subsection{Longitudinal Direction}

Table 6: Base shear for different heights $(\mathrm{kN})$

\begin{tabular}{|c|c|c|c|}
\hline Base Shear & $10 \mathrm{~m}$ & $20 \mathrm{~m}$ & $30 \mathrm{~m}$ \\
\hline IRC:6-2017 & 1079.26 & 409.29 & 237.88 \\
\hline IRC SP:114-2018 & 1349.07 & 511.612 & 470.61 \\
\hline \% Difference & 25 & 25 & 97.84 \\
\hline
\end{tabular}

\subsection{Transverse Direction}

Table 7: Base shear for different heights $(\mathrm{kN})$

\begin{tabular}{|c|c|c|c|}
\hline Base Shear & $10 \mathrm{~m}$ & $20 \mathrm{~m}$ & $30 \mathrm{~m}$ \\
\hline IRC:6-2017 & 1089.49 & 412.337 & 239.22 \\
\hline IRC SP:114-2018 & 1361.86 & 515.42 & 483.21 \\
\hline \% Difference & 25 & 25 & 101.99 \\
\hline
\end{tabular}


As shown in Tables $6 \& 7$, for $10 \mathrm{~m} \& 20 \mathrm{~m}$ height railway over bridges, value of base shear is increased by $25 \%$ in IRC SP:1142018 compared to IRC:6-2017. This is mainly due to importance factor specified in IRC SP:114-2018. However, base shear value is same as bridge without crossing railway lines for $30 \mathrm{~m}$ height because of minimum design acceleration coefficient. Design horizontal seismic coefficient $\left(A_{h}\right)$ for different spans and different heights for bridge crossing railway lines are mentioned in Fig. 4 \& 5 .

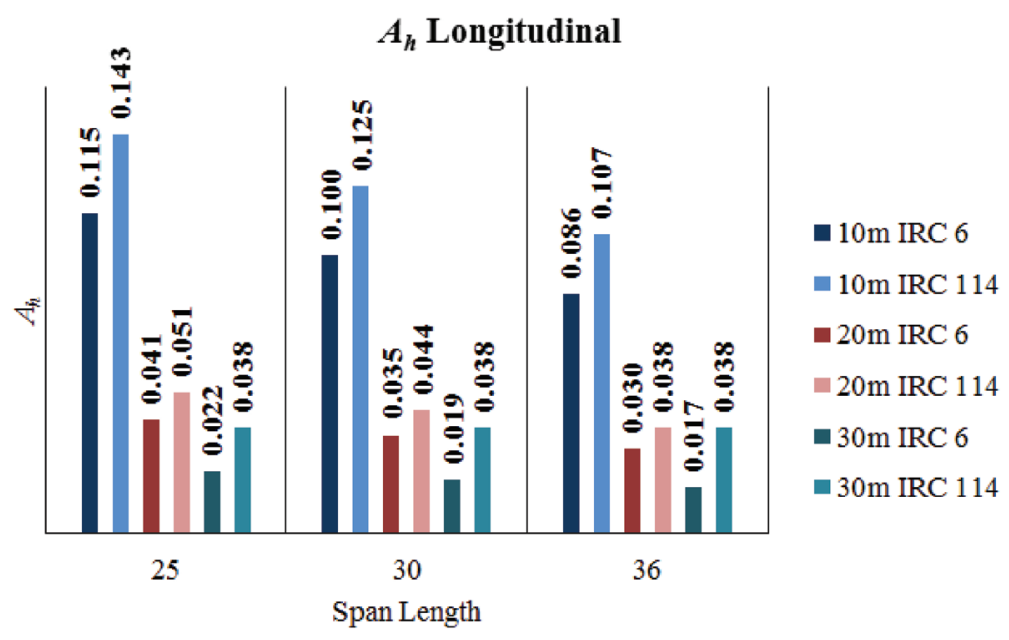

Figure 4: Horizontal Seismic coefficients for different spans \& heights

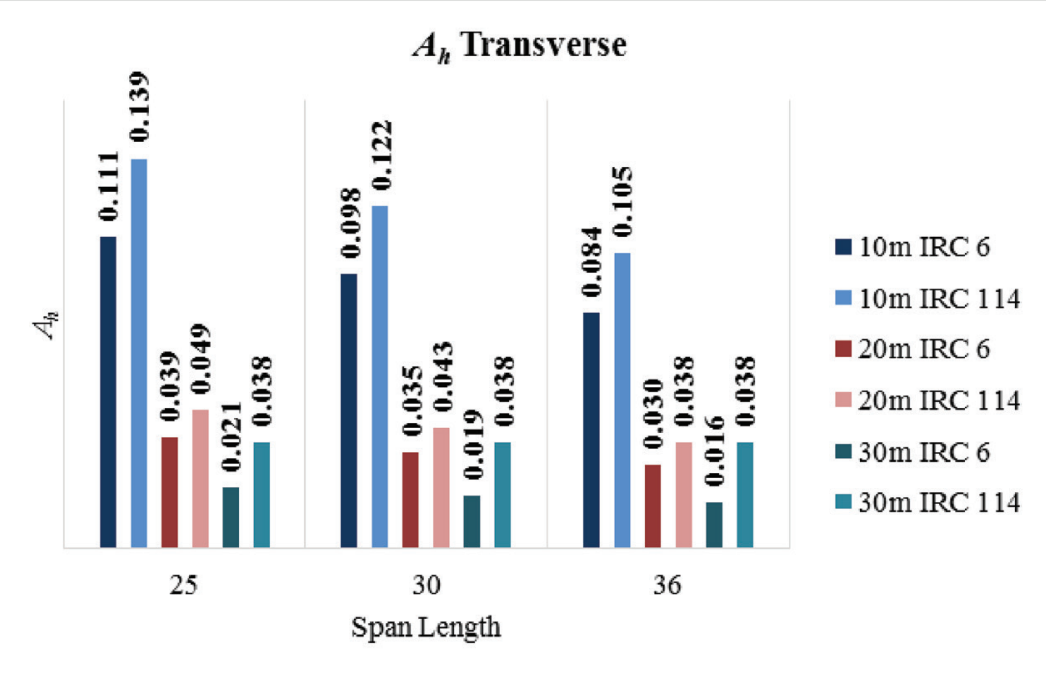

Figure 5: Horizontal seismic coefficients for different spans \& heights 


\subsection{Vertical component for different heights}

Difference in vertical forces as per both codes are mentioned in Table 8.

Table 8: Vertical force for different heights $(\mathrm{kN})$

\begin{tabular}{|c|c|c|c|}
\hline Vertical Force & $10 \mathrm{~m}$ & $20 \mathrm{~m}$ & $30 \mathrm{~m}$ \\
\hline IRC:6-2017 & 726.33 & 274.89 & 159.48 \\
\hline IRC SP:114-2018 & 454.594 & 454.594 & 454.594 \\
\hline \% difference & -37.41 & 65.37 & 185.048 \\
\hline
\end{tabular}

\section{Conclusions}

The seismic analysis of the bridge pier is carried out by considering the height of pier up to $30 \mathrm{~m}$ and value of the base shear is compared according to provisions of both the IRC guidelines IRC:6-2017 \& IRC SP:1142018. Following conclusions are derived from this comparative study:

In case of flexible piers in almost all Zones minimum horizontal seismic coefficient $\left(A_{h}\right)$ given in IRC SP:114-2018 governs.

In case of the bridge crossing more than two railway lines change in importance factor is clearly visible as base shear values are increased to $25 \%$ for $10 \mathrm{~m}$ and $20 \mathrm{~m}$ height of pier.

Base shear value for $30 \mathrm{~m}$ height in IRC SP:114-2018 is 97.84 \% higher than IRC:62017 in the longitudinal direction and $102 \%$ in the transverse direction.

As per new provisions IRC SP:114-2018, the vertical component is independent of the horizontal component and now vertical component depends on the time period of the superstructure. Previously in IRC:6-2017, vertical component was depended on the horizontal coefficient. Due to this, there is a significant difference in vertical forces.

\section{References}

[1] C. V. R. Murty, "Earthquake tip 11", Indian Institute of Technology Kanpur, India, 2005.
[2] V. Desai and V. Vyas, "Comparative study of DDBD and FBD for elevated metro bridge substructure", International Journal of Current Engineering and Scientific Research, vol. 5, no. 4, pp. 75-81, 2018.

[3] A. Rahai and M. Arezoumandi, "Effect of vertical motion of earthquake on RC bridge pier", The $14^{\text {th }}$ World Conference on Earthquake Engineering; October 12-17, Beijing, China, 2008.

[4] IRC SP:114-2018, "Guideline for seismic design of road bridges", Indian Road Congress, New Delhi.

[5] IRC:6-2017, “Standard specifications and code of practice for road bridges (Section: II)", Loads and Load Combinations, Indian Road Congress, New Delhi.

[6] IRC:112-2011, "Code of practice for concrete road bridges”, Indian Road Congress, New Delhi. 